\title{
Impact of Hepatitis C Virus (HCV) Genotypes on Quantification of HCV RNA in Serum by COBAS AmpliPrep/COBAS TaqMan HCV Test, Abbott Antiretroviral Therapy HCV RealTime Assay, and VERSANT HCV RNA Assay ${ }^{\nabla}$
}

\author{
Edouard Tuaillon, ${ }^{1}$ Anne-Marie Mondain, ${ }^{1}$ Laure Ottomani, ${ }^{1}$ Laurent Roudière, ${ }^{1}$ Pascal Perney, ${ }^{2}$ \\ Marie-Christine Picot, ${ }^{4}$ Fabienne Séguret, ${ }^{4}$ François Blanc, ${ }^{2}$ Dominique Larrey, ${ }^{3}$ \\ Philippe Van de Perre, ${ }^{1}$ and Jacques Ducos ${ }^{1 *}$ \\ Unité Hépatites Virales, Laboratoire de Virologie, Hôpital Lapeyronie, ${ }^{1}$ Service de Médecine Interne E, ${ }^{2}$ and Institut des \\ Maladies de l'Appareil Digestif,, ${ }^{3}$ Hôpital Saint-Eloi, and Département de l'Informatique Médicale Hôpital Arnaud de \\ Villeneuve, ${ }^{4} \mathrm{CHU}$ de Montpellier, France
}

Received 16 January 2007/Returned for modification 3 May 2007/Accepted 11 June 2007

The VERSANT HCV RNA 3.0 (bDNA), COBAS AmpliPrep/COBAS TaqMan HCV, and Abbott ART HCV RealTime assays were compared for hepatitis C virus RNA quantification in 158 clinical specimens (genotypes 1 to 5). RNA values differed significantly between methods $(P<0.0001)$, and mean titer differences ranged from 0.01 to $0.50 \log _{10} \mathrm{IU} / \mathrm{ml}$ depending on the genotypes.

Hepatitis $\mathrm{C}$ virus (HCV) infection is a major cause of chronic liver disease. Therapy is monitored by assessing the kinetics of viral clearance based on HCV RNA quantitation (2, $8,12,17)$. Available commercial kits are based on target amplification technology (reverse transcription-PCR) or on signal amplification (branched DNA). Irrespective of the method, the specificity of the hybridization between probe/primer and target is the determining factor of the method's performance. Polymorphisms within the primer/probe-targeted HCV regions may cause significant losses of performance and compromise the accuracy of viral load (VL) measurements. Based on their natural polymorphism, the HCV viruses have been classified into six major genotypes (GT) (14). Most known GT are found in Europe but with different distribution frequencies in various geographic regions (5).

The aim of the present study was to evaluate the performance of the three commercially available HCV RNA quantitative assays, two real-time reverse transcriptase assays, and a signal amplification assay using a panel of serum samples from well-characterized $\mathrm{HCV}$-infected patients with GT1 to GT5.

Serum samples were collected during 2005 from 158 consecutive patients residing in Southern France, with HCV infection confirmed by use of a COBAS Amplicor HCV test, version 2.0 (detection limit of $50 \mathrm{IU} / \mathrm{ml}$; Roche Diagnostics, Mannheim, Germany). Each serum sample was divided into three aliquots and stored at $-80^{\circ} \mathrm{C}$ within $4 \mathrm{~h}$ of blood sampling. HCV genotype was determined by using a VERSANT HCV genotyping assay (line probe assay) (Bayer Diagnostics, Tarrytown, NY).

\footnotetext{
* Corresponding author. Mailing address: Unité Hépatites Virales, Laboratoire de Virologie, Hôpital Lapeyronie, av. du Doyen G. Giraud, 34295 Montpellier, France. Phone: 33467338 336. Fax: 33467 338 334. E-mail: j-ducos@chu-montpellier.fr.

${ }^{\nabla}$ Published ahead of print on 20 June 2007.
}

All samples were processed in accordance with the manufacturer's instructions. The COBAS Ampliprep/COBAS TaqMan HCV test (CAP/CTM) (Roche Diagnostics, Mannheim, Germany) requires $1,050 \mu \mathrm{l}$ of serum with a sample input volume of $850 \mu \mathrm{l}$ and with a quantification range of 15 to $6.9 \times$ $10^{7} \mathrm{IU} / \mathrm{ml}\left(1.18\right.$ to $\left.7.84 \log _{10}\right)$. The HCV RealTime assay (antiretroviral therapy [ART]; Abbott Laboratories, Abbott Park, IL) requires $1,000 \mu \mathrm{l}$ of serum, with a quantification range of 12 to $1 \times 10^{7} \mathrm{IU} / \mathrm{ml}\left(1.08\right.$ to $\left.7.0 \log _{10}\right)$. The Abbott ART HCV kit was used in conjunction with the Abbott m1000 extraction and the m2000rt amplification systems. The VERSANT HCV RNA 3.0 (bDNA) assay (Bayer Diagnostics, Tarrytown, NY) requires $50 \mu \mathrm{l}$ of plasma or serum, with a quantification range of 615 to $7.7 \times 10^{6} \mathrm{IU} / \mathrm{ml}$ (2.79 to 6.89 $\log _{10}$ ) with the VERSANT 340 analyzer.

Values outside the quantification ranges were exclude from comparison and correlation analyses. Mean values \pm standard deviations (SD) were determined for each method and compared using the Student paired $t$ test for global results. Differences in titer values and strengths of agreement in titer results between two assay methods were assessed by Bland-Altman plot analysis $(2,3)$. To detect a proportional bias, the slope of the regression line of the differences against the means is tested against zero. Deming regression models were used to assess the distance between the regression line and the bisecting line (1). The relationship between the assays was regarded as linear when the slope of the Deming regression analysis approaches 1 .

One hundred forty-eight patient samples were successfully quantified by the three assays. HCV genotypes were represented as follows: 101 were GT1 (68\%), 12 were GT2 (8\%), 18 were GT3 (12\%), 15 were GT4 (10\%), and 2 were GT5 (1\%). Seven samples were undetectable by bDNA, with values ranging from 44 to $677 \mathrm{IU} / \mathrm{ml}$ by CAP/CTM and ART. For three samples, the values were higher than the bDNA detection limit $\left(>7.7 \times 10^{6} \mathrm{IU} / \mathrm{ml}\right)$. The mean $\mathrm{HCV}$ RNA values differed 

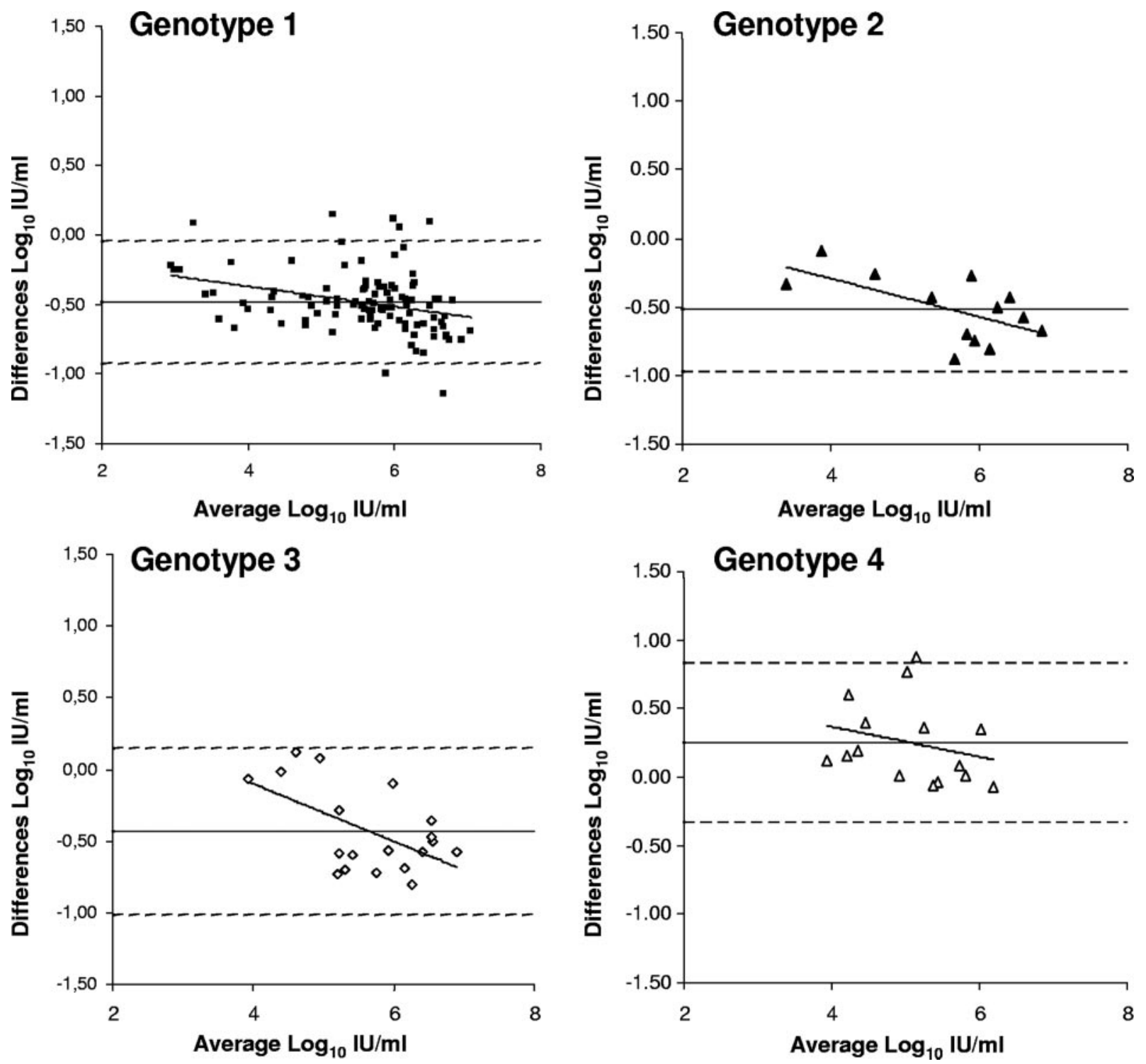

FIG. 1. Bland-Altman plot of titer differences (expressed in $\log _{10} \mathrm{IU} / \mathrm{ml}$ ) between bDNA and CAP/TAM over the range of quantitative titers obtained by both assays. The horizontal solid lines indicate the mean titer difference values, the dashed lines represent the \pm 2 -SD limits from the means, and diagonal solid lines are the linear regression lines. $\mathbf{\square}$, GT1 $(n=102$ clinical specimens); $\boldsymbol{\Delta}$, GT2 $(n=13) ; \diamond$, GT3 $(n=19) ; \Delta$, GT4 $(n=15)$.

significantly between the methods, with mean titer differences \pm SD of $-0.40 \pm 0.32 \log _{10} \mathrm{IU} / \mathrm{ml}$ (bDNA versus CAP/CTM; $P<$ $0.0001),-0.16 \pm 0.26 \log _{10} \mathrm{IU} / \mathrm{ml}(\mathrm{bDNA}$ versus ART; $P<$ $0.0001)$ and $+0.23 \pm 0.40 \log _{10} \mathrm{IU} / \mathrm{ml}(\mathrm{CAP} / \mathrm{CTM}$ versus ART; $P<0.0001)$. The mean titer differences between bDNA and $\mathrm{CAP} / \mathrm{CTM}$ and bDNA and ART tended to increase with VL above $5.4 \log _{10} \mathrm{IU} / \mathrm{ml}$, when the mean titer difference reached $-0.51 \log _{10} \mathrm{IU} / \mathrm{ml},(n=109$ patients samples $)$ and $-0.44 \log _{10}$ $\mathrm{IU} / \mathrm{ml}(n=100)$, respectively.

Comparisons of results obtained by bDNA versus CAP/ CTM and sorted by genotype indicated a linear relationships between the two methods; slopes (95\% confidence intervals) were as follows: 1.08 (1.04 to 1.13) for GT1, 1.11 (1.02 to 1.20) for GT2, 1.23 (1.08 to 1.38) for GT3, and 1.11 (0.88 to 1.34 ) for GT4. Comparison of HCV RNA VL gave lower values with
bDNA versus CAP/CTM for GT1, GT2, and GT3 viruses, while it was the opposite for GT4 viruses, with mean titer differences \pm SD of $-0.49 \pm 0.21 \log _{10} \mathrm{IU} / \mathrm{ml}(P<0.0001)$ for GT1,$-0.52 \pm 0.21 \log _{10} \mathrm{IU} / \mathrm{ml}(P<0.0001)$ for GT2, $-0.43 \pm$ $0.30 \log _{10} \mathrm{IU} / \mathrm{ml}(P<0.0001)$ for GT3, and $+0.25 \pm 0.30 \log _{10}$ $\mathrm{IU} / \mathrm{ml}(P<0.001)$ for GT4 (Fig. 1). Titer differences of -0.46 and $-0.49 \log _{10} \mathrm{IU} / \mathrm{ml}$ were obtained among the two GT5 HCV RNA samples.

Comparisons of results obtained by bDNA versus ART showed the following slopes (95\% confidence intervals): 1.12 (1.06 to 1.18) for GT1, 1.21 (1.05 to 1.37) for GT2, 1.07 (0.98 to 1.16) for GT3, and 1.04 (0.87 to 1.21) for GT4. Means of the VL were moderately lower with bDNA, with mean titer differences \pm SD of $-0.11 \pm 0.26 \log _{10} \mathrm{IU} / \mathrm{ml}(P<0.0001)$ for GT1, $-0.23 \pm 0.26 \log _{10} \mathrm{IU} / \mathrm{ml}(P=0.02)$ for GT2, $-0.38 \pm 0.16$ 

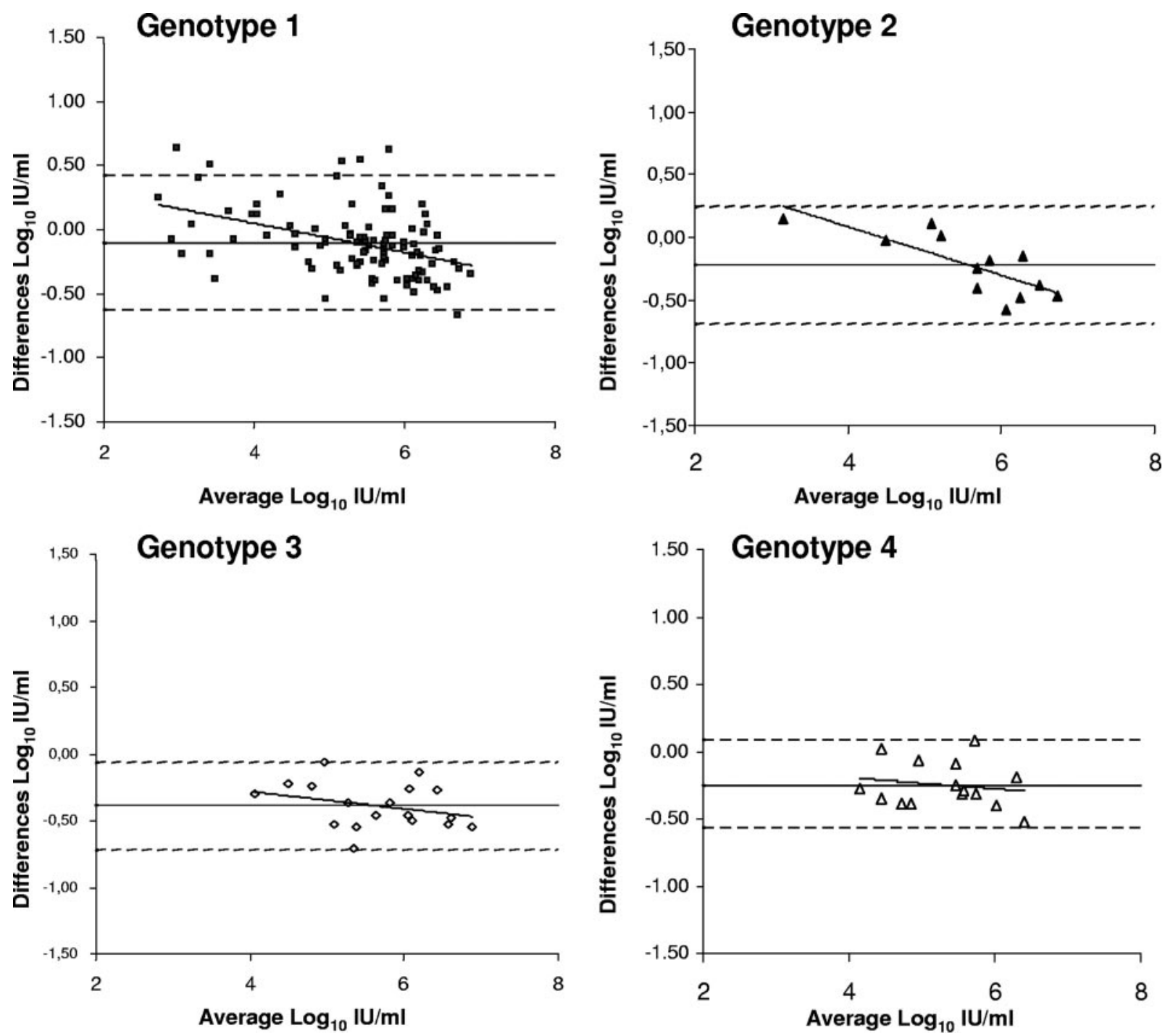

FIG. 2. Bland-Altman plot of titer differences (expressed in $\log _{10} \mathrm{IU} / \mathrm{ml}$ ) between bDNA and ART over the range of quantitative titers obtained by both assays. The horizontal solid lines indicate the mean titer difference values, the dashed lines represent the \pm 2 -SD limits from the means, and diagonal solid lines are the linear regression lines. $\mathbf{\square}$, GT1 $(n=102$ clinical specimens $)$; $\boldsymbol{\Delta}$, GT2 $(n=13) ; \diamond$, GT3 $(n=$ $19) ; \triangle$ GT4 $(n=15)$.

$\log _{10} \mathrm{IU} / \mathrm{ml}(P<0.0001)$ for GT3, $-0.24 \pm 0.25 \log _{10} \mathrm{IU} / \mathrm{ml}$ $(P<0.0001)$ for GT4 (Fig. 2$)$, and +0.23 and $+0.12 \log _{10}$ $\mathrm{IU} / \mathrm{ml}$ for the two GT5 isolates.

Comparisons of results obtained by CAP/CTM versus ART showed the following slopes ( $95 \%$ confidence intervals): 0.97 (0.92 to 1.02) for GT1, 0.91 (0.80 to 1.03$)$ for GT2, 1.15 (0.99 to 1.32) for GT3, and 1.07 (0.82 to 1.30) for GT4. Data analysis of HCV RNA differences (CAP/CTM versus ART) according to $\mathrm{HCV}$ genotypes indicated mean titer differences $\pm \mathrm{SD}$ of $+0.37 \pm 0.28 \log _{10} \mathrm{IU} / \mathrm{ml}(P<0.0001)$ for $\mathrm{GT} 1,+0.30 \pm 0.031$ $\log _{10} \mathrm{IU} / \mathrm{ml}(P=0.034)$ for GT2, and $+0.01 \pm 0.32 \log _{10} \mathrm{IU} / \mathrm{ml}$ $(P>0.5)$ for GT3, while the mean difference is $-0.50 \pm 0.38$ $\log _{10} \mathrm{IU} / \mathrm{ml}(P<0.001)$ for GT4 (Fig. 3). Titer differences of +0.72 and $+0.34 \log _{10} \mathrm{IU} / \mathrm{ml}$ were obtained among the two GT5 isolates.

The study compared the Bayer bDNA, Roche CAP/CTM, and Abbott ART assays using a large number of sera from
HCV-infected patients representative of the HCV genetic diversity observed in Southern France (unpublished data). Despite the use of standardized international units for expressing quantitative HCV RNA values, significant differences in the mean $\log _{10} \mathrm{IU} / \mathrm{ml}$ values obtained by these methods exist (10). HCV genotypes had an impact on the divergence between the assay results. Indeed, HCV RNA VL obtained by CAP/CTM using GT4 samples were lower than those of other genotypes, both by comparisons to the competitor methods and by internal comparisons with the CAP/CTM results on GT1 to GT3 samples. This suggests that GT4 HCV samples were underquantified by CAP/CTM, with these results being consistent with data from previous reports $(4,13)$. Although some authors assumed that ART may also underquantify GT4 (4), quantifications of GT4 and GT1 to GT3 isolates were equivalent between bDNA and ART in our study. The bDNA assay underestimates HCV RNA GT1 to GT3 compared with results 

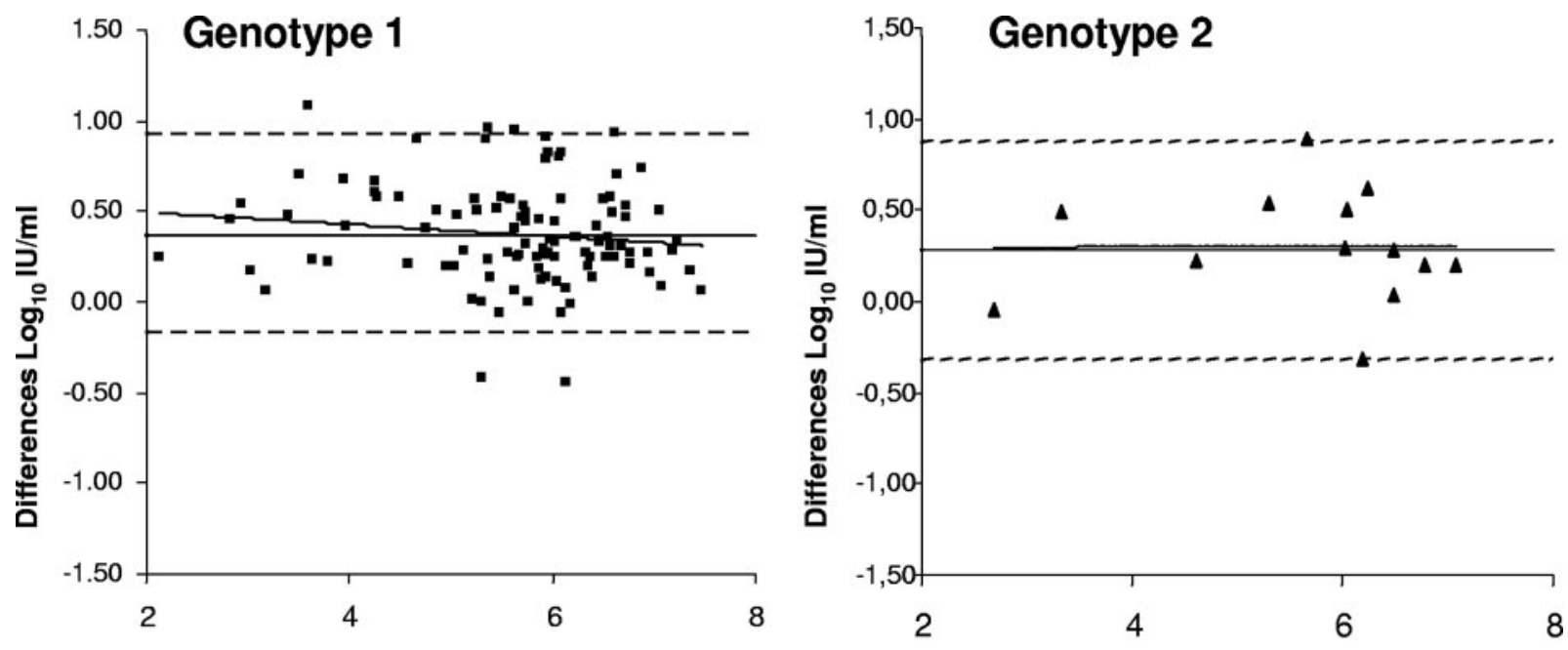

Average $\log _{10} \mathrm{IU} / \mathrm{ml}$

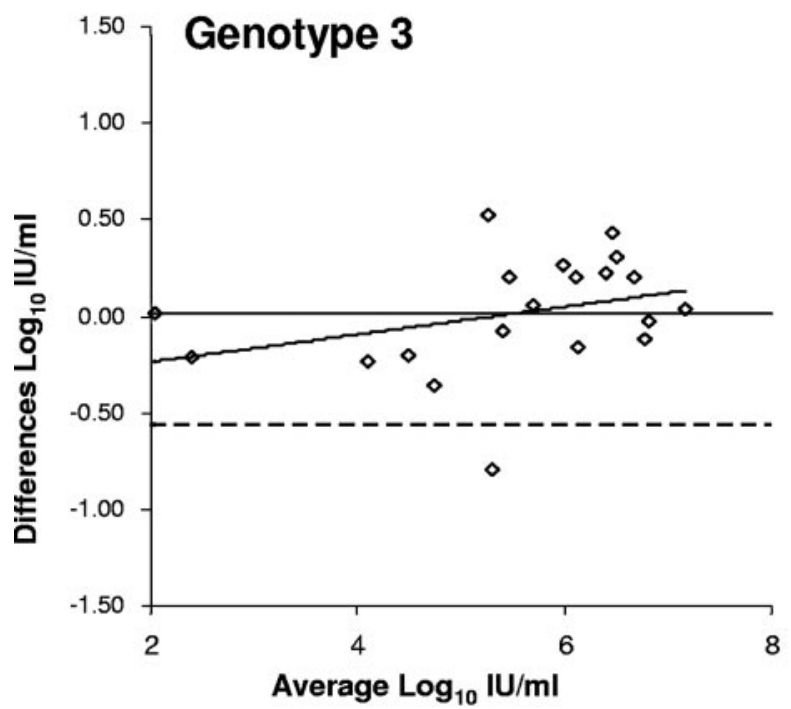

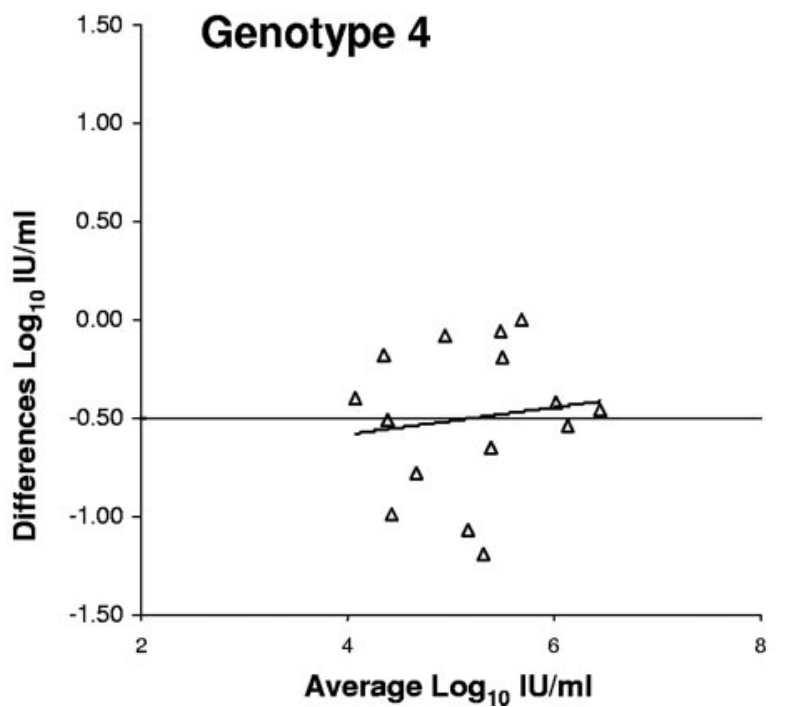

FIG. 3. Bland-Altman plot of titer differences (expressed in $\log _{10} \mathrm{IU} / \mathrm{ml}$ ) between CAP/TAM and ART over the range of quantitative titers obtained by both assays. The horizontal solid lines indicate the mean titer difference values, the dashed lines represent the \pm 2 -SD limits from the means, and diagonal solid lines are the linear regression lines. $\mathbf{D}$, GT1 $(n=102$ clinical specimens); $\boldsymbol{\Delta}$, GT2 $(n=13) ; \diamond, \mathrm{GT3}(n=19) ; \triangle$, GT4 $(n=15)$.

of CAP/CTM (4, 13) and ART (13) assays, but we found a mean titer difference of only $0.11 \log _{10} \mathrm{IU} / \mathrm{ml}$ for GT1 by comparing bDNA versus ART. Overall, in our single-laboratory study, a lesser variation in quantitative HCV RNA measures was observed than was observed in a recent multiplelaboratory study evaluating the same three commercially available HCV RNA quantitative assays (4). Conceivably, the multilaboratory study design may have contributed to result consistency.

VL testing has a critical role in guiding clinicians to make informed therapeutic decisions when faced with chronically infected HCV patients. Recent reports suggested the establishment HCV VL thresholds for guiding clinical decision making. A consensual level of $800,000 \mathrm{IU} / \mathrm{ml}$ has been proposed by several research groups to be a critical threshold for therapeutic decisions $(6,7,9,11,16)$. Similarly, thresholds of 100,000 $\mathrm{IU} / \mathrm{ml}$ at week 4 and of 10,000 IU/ml at weeks 8 and 12 have been accepted as being early predictors of a favorable treatment outcome (15). Strict thresholds suffer, however, from unsatisfactory agreement between commercially available assays. It is therefore important to consistently use the same HCV RNA quantitative method throughout follow-up for an $\mathrm{HCV}$ patient on therapy. Also, interpretation of $\mathrm{HCV}$ RNA data from clinical trials should take into account the method used for viral quantitation. Moreover, since HCV RNA quantification is genotype dependent, the detection limits may be not equivalent for all genotypes and in some cases may result in erroneous conclusions of clearance of circulating $\mathrm{HCV}$.

We believe that it is important to undertake repeated evaluations of the accuracy and sensitivity of commercial HCV RNA kits by using clinical samples with a diversity of viral GT that is representative of the GT distribution where the test is intended for use. 
This study was supported by the Centre Hospitalier Universitaire of Montpellier.

We are grateful to M. L. Collins for helpful discussion and carefully reading the manuscript.

\section{REFERENCES}

1. Armitage, P., G. Berry, and J. N. S. Matthews. 2002. Statistical methods in medical research. Blackwell Science, Oxford, Malden, MA.

2. Berg, T., C. Sarrazin, E. Herrmann, H. Hinrichsen, T. Gerlach, R. Zachoval, B. Wiedenmann, U. Hopf, and S. Zeuzem. 2003. Prediction of treatment outcome in patients with chronic hepatitis C: significance of baseline parameters and viral dynamics during therapy. Hepatology 37:600-609.

3. Bland, J. M., and D. G. Altman. 1986. Statistical methods for assessing agreement between two methods of clinical measurement. Lancet i:307-310.

4. Caliendo, A. M., A. Valsamakis, Y. Zhou, B. Yen-Lieberman, J. Andersen, S Young, A. Ferreira-Gonzalez, G. J. Tsongalis, R. Pyles, J. W. Bremer, and N. S. Lurain. 2006. Multilaboratory comparison of hepatitis C virus viral load assays. J. Clin. Microbiol. 44:1726-1732.

5. Davis, G. L. 2003. New approaches and therapeutic modalities for the prevention and treatment of recurrent HCV after liver transplantation. Liver Transpl. 9:S114-S119.

6. Forns, X., and J. Costa. 2006. HCV virological assessment. J. Hepatol. 44:S35-S39.

7. Fried, M. W., M. L. Shiffman, K. R. Reddy, C. Smith, G. Marinos, F. L Goncales, Jr., D. Haussinger, M. Diago, G. Carosi, D. Dhumeaux, A. Craxi, A. Lin, J. Hoffman, and J. Yu. 2002. Peginterferon alfa-2a plus ribavirin for chronic hepatitis C virus infection. N. Engl. J. Med. 347:975-982.

8. Gallegos-Orozco, J. F., A. P. Fuentes, M. A. Olivera-Martinez, G. GutierrezReyes, D. Cortina, J. A. Oregel, C. Perez-Pruna, M. S. Sixtos, S. CruzCastellanos, L. E. Soto-Ramirez, R. Rodriguez-Diaz, L. Fuentes-Romero, M. C. Gutierrez-Ruiz, and D. Kershenobich. 2003. Early HCV RNA changes in patients with chronic hepatitis $\mathrm{C}$ treated with peginterferon alfa $2 \mathrm{~b}$ and ribavirin. Rev. Investig. Clin. 55:138-142.

9. Hadziyannis, S. J., H. Sette, Jr., T. R. Morgan, V. Balan, M. Diago, P. Marcellin, G. Ramadori, H. Bodenheimer, Jr., D. Bernstein, M. Rizzetto, S. Zeuzem, P. J. Pockros, A. Lin, and A. M. Ackrill. 2004. Peginterferonalpha2a and ribavirin combination therapy in chronic hepatitis C: a randomized study of treatment duration and ribavirin dose. Ann. Intern. Med. 140:346-355.
10. Halfon, P., G. Penaranda, M. Bourliere, H. Khiri, M. F. Masseyeff, and D. Ouzan. 2006. Assessment of early virological response to antiviral therapy by comparing four assays for HCV RNA quantification using the international unit standard: implications for clinical management of patients with chronic hepatitis C virus infection. J. Med. Virol. 78:208-215.

11. Manns, M. P., J. G. McHutchison, S. C. Gordon, V. K. Rustgi, M. Shiffman, R. Reindollar, Z. D. Goodman, K. Koury, M. Ling, and J. K. Albrecht. 2001. Peginterferon alfa-2b plus ribavirin compared with interferon alfa-2b plus ribavirin for initial treatment of chronic hepatitis $\mathrm{C}$ : a randomised trial. Lancet 358:958-965.

12. NIH. 2002. NIH consensus statement on management of hepatitis C. NIH Consens. State Sci. Statements 19:1-46.

13. Sarrazin, C., B. C. Gartner, D. Sizmann, R. Babiel, U. Mihm, W. P. Hofmann, M. von Wagner, and S. Zeuzem. 2006. Comparison of conventional PCR with real-time PCR and branched DNA-based assays for hepatitis $\mathrm{C}$ virus RNA quantification and clinical significance for genotypes 1 to 5. J. Clin. Microbiol. 44:729-737.

14. Simmonds, P., J. Bukh, C. Combet, G. Deleage, N. Enomoto, S. Feinstone, P. Halfon, G. Inchauspe, C. Kuiken, G. Maertens, M. Mizokami, D. G. Murphy, H. Okamoto, J. M. Pawlotsky, F. Penin, E. Sablon, I. T. Shin, L. J. Stuyver, H. J. Thiel, S. Viazov, A. J. Weiner, and A. Widell. 2005. Consensus proposals for a unified system of nomenclature of hepatitis $\mathrm{C}$ virus genotypes. Hepatology 42:962-973.

15. Terrault, N. A., J. M. Pawlotsky, J. McHutchison, F. Anderson, M. Krajden, S. Gordon, I. Zitron, R. Perrillo, R. Gish, M. Holodniy, and M. Friesenhahn. 2005. Clinical utility of viral load measurements in individuals with chronic hepatitis C infection on antiviral therapy. J. Viral Hepat. 12:465-472.

16. von Wagner, M., M. Huber, T. Berg, H. Hinrichsen, J. Rasenack, T. Heintges, A. Bergk, C. Bernsmeier, D. Haussinger, E. Herrmann, and S. Zeuzem. 2005. Peginterferon-alpha-2a (40KD) and ribavirin for 16 or 24 weeks in patients with genotype 2 or 3 chronic hepatitis C. Gastroenterology 129:522-527.

17. Zeuzem, S., J. M. Pawlotsky, E. Lukasiewicz, M. von Wagner, I. Goulis, Y. Lurie, E. Gianfranco, J. M. Vrolijk, J. I. Esteban, C. Hezode, M. Lagging, F. Negro, A. Soulier, E. Verheij-Hart, B. Hansen, R. Tal, C. Ferrari, S. W. Schalm, and A. U. Neumann. 2005. International, multicenter, randomized, controlled study comparing dynamically individualized versus standard treatment in patients with chronic hepatitis C. J. Hepatol. 43:250-257. 